\title{
3 最近の素材伝送技術
}

\section{正会員斎藤利 夫}

キーワード

素材伝送, HDTV, ディジタルFPU, SNG, STL/TTL, TSL, QAM, OFDM

\section{1. ま え がき}

2003年の年末には, 基幹放送と位置付けられている地上 波デジタル放送が開始される予定である. BSデジタル放送, CSデジタル放送につづき, テレビ放送のディジタル化の仕 上げが行われる。地上波デジタル放送の開始に向け, SNG (Satellite News Gathering System), FPU (Field Pick-up Unit), TSL (Transmitter to Studio Link) といったHDTV 素材伝送システムと, 中継局への番組伝送に必要なSTL (Studio to Transmitter Link)/TTL (Transmitter to Transmitter Link) 装置の導入・整備が進められている. HDTVの素材伝送のキーデバイスであるHDTV用エンコー ダは，まだまだ外形・重量とも大きいが，2003年までに， これをはがきサイズにまで小型化し，FPU本体に内蔵する 目標で開発が進められており, 周辺機器を含めたHDTV用 素材伝送設備の小型・軽量化も一気に進むことが期待され る.ここでは, HDTV素材伝送用設備と中継局への番組伝 送に必要なSTL/TTL設備について, その技術基準と開発 状況を報告する。

\section{HD-SNG設備}

\subsection{SNG回線のディジタル化}

素材伝送用設備のディジタル化は, SNG回線において最 も早く導入された。これは, SNG回線の運用コストの中で 占める衛星回線使用料が高額であったため, ディジタル化 による使用带域幅の削減が直ちに運用コストに反映し，伝 送画質の改善効果とともに，ディジタル化のメリットが見 え易かったためと考えられる。

SNG設備は，1989年にアナログFM方式で運用が開始さ れた。 その後, 1995年頃からSDTVを対象に, ディジタル 化の検討が行われ，1997年頃から実用設備の導入が開始さ れ，1999年には大部分のSNG設備がディジタル化された. SNG用に使用されている通信衛星用トランスポンダの周波 数帯域幅がほとんど $36 \mathrm{MHz}$ で，アナログ運用では，これを

†株式会社東京放送 技術局技術管理センター 技術推進担当 "Recent Trends of Contribution and Distribution Systems for HDTV" by Toshio Saito (Technical Administration Division of TV Technology, Tokyo Broadcasting System, Inc., Tokyo)
SDTV2回線に分割使用していたが，ディジタル化するこ とで，これをSDTV4回線として使用できるようになり， 運用コストの低減とともに，4回線化しても，アナログ運 用時より画質の改善を図ることが可能になったためであ る。また, SNGシステムは, 放送事業者のネット系列ごと に運用されているため, ネットぐるみの移行が必要という 事情もあった。また，本線系のディジタル化にあわせ， DAMA (Demand Assignment Multiple Access) システム の導入なども, ディジタル化の促進に寄与したものと思わ れる.さらに, 送信電力が小さくて済むことから, システ ムの小型・軽量化にも取組まれ, ポータブルSNGシステム の開発なども行われた。

\subsection{SNGによるディジタルHDTV伝送}

SNGによるディジタルHDTV伝送の検討は1997年頃から 開始され，2000年7月には，ARIB (電波産業界) 標準規格1) が策定されるなど, HDTVの素材伝送手段としては, 多值 FM-FPUとともに, 最も早くから検討が行われ, 実運用の 実績も多い。これは, SNG用の衛星トランスポンダの伝送 帯域幅 $(36 \mathrm{MHz})$ を, 8PSK変調で使用すると, 約 $80 \mathrm{Mbps}$ 〜90Mbpsの伝送情報レートが確保でき, HDTVの素材伝 送に比較的適合しやすいものであったことも大きな要因で あった。

HDTV用素材伝送回線は，このようにSNG回線からスタ 一トしたため, その後にHDTV用素材伝送回線として技術 基準の策定が進められたディジタルFPUでも，SNG回線と タンデム接続時の画質劣化が生じないよう, SNG回線との 相互互換 (シームレス接続) を前提にパラメータの決定が行 われた. 表1に素材伝送回線(SNG/QAM-FPU/OFDM-FPU) 用の運用モードとその情報源符号化, および, 伝送路符号 化における主要パラメータを示す. 最近ではスタッフィン グ設定の自由度が増え, 現在開発途上にあるOFDM-FPUで は，最大伝送容量を超えない範囲であれば，どの運用モー ドでもシームレス接続が可能になりつつある.

現状ではHDTV素材伝送の品質基準が確定できないた め, 多様な運用モードを設定しているが, 今後は運用実績 を重ねた上で，最適な運用モードが絞られていくものと思 われる。またSNG回線では, 技術連絡用回線, 制作連絡用 回線，マイナスワン送り返し回線，DAMA用などの番組制 


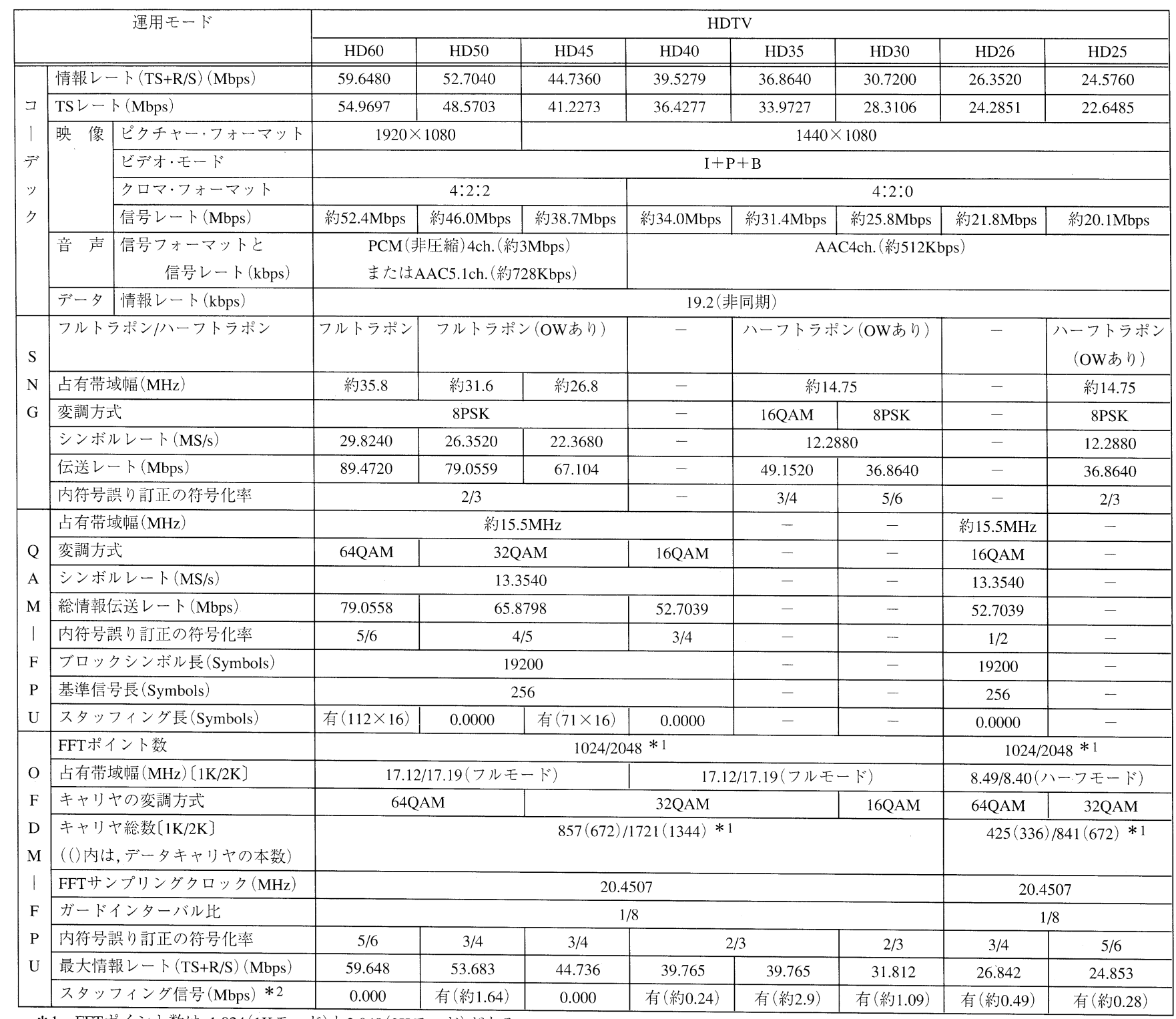

*1 FFTポイント数は, 1,024(1Kモード) と2,048(2Kモード)がある.

*2 OFDM-FPUについては, 最大情報レート以下の信号入力が必要なスタッフィンクが, 自動的にセットされるシステムを想定した。

表 1 素材伝送回線の運用モードと主要パラメータ

作用の通信回線 (OW回線) を同一トランスポンダ上に構築 しているため, OW回線用の周波数領域を確保できない運 用モードは，回線運用上からはあまり望ましいものとはい えない.

最近になって, 衛星回線にも16QAM変調方式の使用が 許可された。16QAM変調方式を使用することにより，八 ープトランスポンダ带域 (OW回線の伝送領域を確保する ため，占有周波数帯幅としては15MHz以下とする必要があ る)で約49.2Mbpsの伝送レートを確保できるため，運用コ スト削減の観点からも，ハーフトランスポンダ帯域での HDTV素材伝送の実現が期待されている．HD-SNG中継車 の送信規模は，最大送信出力： $600 \mathrm{~W}(350 \mathrm{~W}-\mathrm{TWT} \mathrm{PA} \times 2)$, 空中線 $: 2 \mathrm{~m} \times 1 \mathrm{~m}(1.4 \mathrm{~m} \phi$ 相当, 利得 $=44.9 \mathrm{~dB})$, 送信給電
線損失 : $2.2 \mathrm{~dB}$ ，程度のシステムが標準的である。このよ うな条件下での回線設計例を表2に，ハーフトランスポン ダ運用の16QAM変調方式と8PSK変調方式のBER特性の実 測值を図1に示した。

16QAM変調方式を使用した運用モード (HD35) は, 所要 $\mathrm{C} /(\mathrm{N}+\mathrm{I})$ が高くなるため, 運用上の注意が必要であり, 回 線設計例から見る限りマージンの少ない回線構成となるこ とが懸念される，そこで，実運用状態での回線マージンを 知る目的で，回線設計例と同一条件において，実運用状態 の回線設定から，送信出力を漸減させて，映像信号の波綻 (映像信号のフリーズ点とした。このため, 回線設計例の 所要 $\mathrm{C} /(\mathrm{N}+\mathrm{I})$ とは異なる) 点までの送信機出力を測定した。 現場レベルでの測定であるため，測定精度が充分とはいえ 


\begin{tabular}{|c|c|c|c|c|c|c|c|c|c|}
\hline \multirow{2}{*}{\multicolumn{2}{|c|}{ 送信場所 }} & \multicolumn{3}{|c|}{ 運用モード } & \multirow{3}{*}{$\frac{\text { 限界 } \mathrm{C} / \mathrm{N}(\mathrm{dB})}{}$} & \multirow{3}{*}{$\frac{\operatorname{EIRP}(\mathrm{dBm})}{62.8}$} & \multirow{3}{*}{$\frac{\text { 送信出力 (W) }}{101.9}$} & \multirow{3}{*}{$\frac{\mathrm{C} /(\mathrm{N}+\mathrm{I})(\mathrm{dB})}{15.1}$} & \multirow{3}{*}{$\begin{array}{c}\text { 回線稼働率 }(\%) \\
99.950\end{array}$} \\
\hline & & \multirow{2}{*}{$\frac{\text { モード }}{\text { HD60 }}$} & \multirow{2}{*}{$\begin{array}{c}\text { 変調/誤り訂正 } \\
8 \mathrm{PSK}, 2 / 3\end{array}$} & \multirow{2}{*}{$\begin{array}{l}\frac{\text { 帯域幅 }}{} \\
\text { フル }\end{array}$} & & & & & \\
\hline 東 & 京 & & & & & & & & \\
\hline & & HD45 & $8 \mathrm{PSK}, 2 / 3$ & フル & 11.5 & 61.9 & 82.8 & 15.4 & 99.961 \\
\hline & & HD35 & 16QAM,3/4 & ハーフ & 14.2 & 58.9 & 41.5 & 15.0 & 99.939 \\
\hline & & HD30 & 8PSK,5/6 & ハーフ & 13.4 & 58.9 & 41.5 & 15.0 & 99.957 \\
\hline & 縄 & HD60 & $8 \mathrm{PSK}, 2 / 3$ & フル & 11.5 & 65.6 & 196.8 & 13.8 & 99.512 \\
\hline & 覇) & HD45 & $8 \mathrm{PSK}, 2 / 3$ & フル & 11.5 & 65.6 & 196.8 & 14.9 & 99.727 \\
\hline & & HD35 & 16QAM,3/4 & ハーフ & 14.2 & 63.3 & 114.3 & 15.0 & 99.651 \\
\hline & & HD30 & 8PSK,5/6 & ハーフ & 13.4 & 63.3 & 114.3 & 15.0 & 99.765 \\
\hline 条 & 件 & \multicolumn{8}{|c|}{$\begin{array}{l}\text { 使用衛星 }=\text { Super Bird }-\mathrm{A}, \text { 送信空中線利得 }=44.9 \mathrm{~dB}(1.4 \mathrm{~m} \phi) \text {, 送信給電線損失 }=2.2 \mathrm{~dB} \\
\text { 降雨時最大HPA出力 }=197 \mathrm{~W}, \text { フルは带域幅 }=\text { 約 } 27 \sim 36 \mathrm{MHz} \text {, ハーフはは約 } 14.5 \mathrm{MHz} \\
\text { 受信場所 }=\text { 東京, 受信空中線利得 }=58.6 \mathrm{~dB}(7.6 \mathrm{~m} \phi) \text {, 受信 } \mathrm{G} / \mathrm{T}=33.5 \mathrm{~dB} / \mathrm{K}\end{array}$} \\
\hline
\end{tabular}

表2 SNGディジタル回線の回線設計 (例)

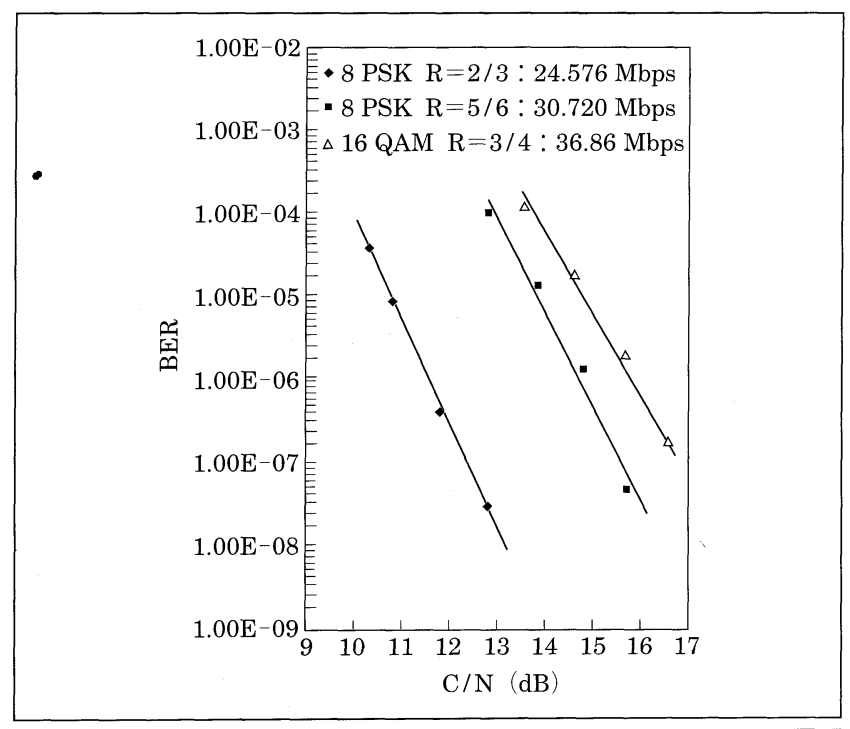

図 1 SNGディジタル回線のBER特性 (8PSKと16QAM)

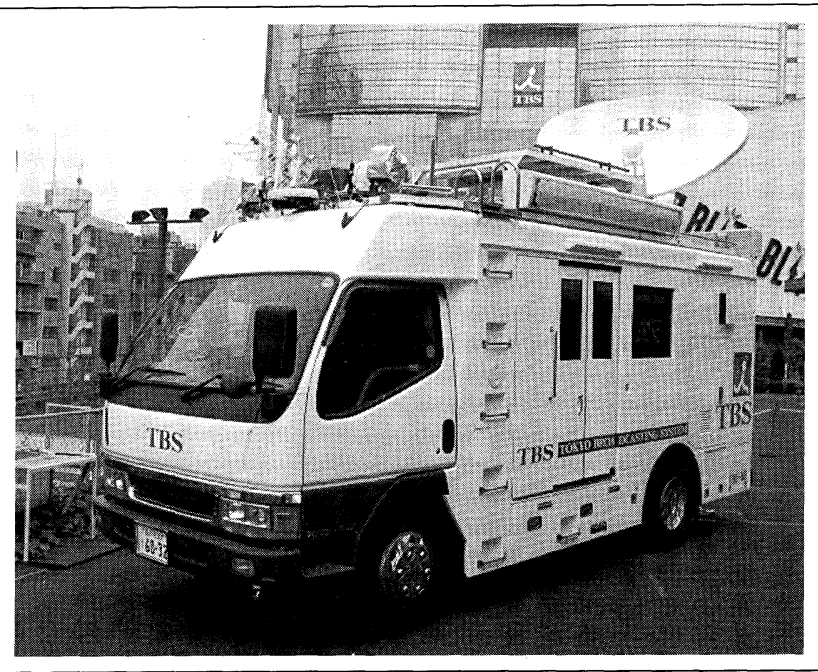

図2 HD-SNG中継車の外観図の一例（TBS32）
ないがHD35モードでは，実運用設定状態の送信機出力は 約18.5W，受信C/ (N+I) は約19.4dBであった。送信出力を 漸隇させ，映像信号が破綻したときの送信機出力は $2.8 \mathrm{~W}$, 受信 $\mathrm{C} /(\mathrm{N}+\mathrm{I})$ は約11.6dBであった。送信機出力の比でみれ ば約 $8.2 \mathrm{~dB}$ である，回線設計では，衛星回線や地上送受信 設備のパラメー夕等について大きめのマージンを見込んで いる（他の運用モードについても同様の測定結果が得られ ている)ため，実運用においては，HD35モードの使用に大 きな問題はないと考えられる.

現状のコーデックの特性から見ると, HD35モードの情 報レートでは，一般のHD番組の伝送に使用することにつ いては疑問があるが，今後のコーデックや衛星伝送系の特 性改善により，16QAM変調方式によるハーフトランスポ ンダ運用が，需要增しの見込まれるHD-SNG伝送への有効 な手段として活用されるものと期待される。

\subsection{HD-SNG中継車}

最新モデルのHD-SNG中継車の外観図 (例)を図2に示す. この中継車は, 前述のようなSNG伝送設備と，2台の常載 HDカメラ (最大 4 台まで拡張可能), HDE (デイジタル特殊 効果ユニット) 付 8 入力スイッチャと 2 台のHD-VTRなど, 中規模の番組制作が可能な設備を，車長 $5.75 \mathrm{~m}$ ，車幅 $2.1 \mathrm{~m}$ のキャンター(三菱自動車) ボディに装備したものである.

\section{3. ディジタルFPU装置}

FPU設備のディジタル化は, 周波数割当が逼迫するなか, 周波数利用効率の一層の向上と, HDTV素材の伝送手段の 確保という放送事業者の要求を受け，「QAM-FPU方式の 技術的条件」が2000年3月に，「OFDM-FPU方式の技術的条 件」が2000年10月に情報通信審議会情報通信技術分科会か ら答申され，制度整備が進められた。

一方，今後のマイクロ波帯の利用に関する基本的な問題 として，FWA，NWA，無線LAN，第4世代世移動通信シ ステムなどに使用する周波数の確保を目的とした審議が進 
められており，そのための周波数利用効率の向上や周波数 割当の見直しが課題 ${ }^{2)}$ とされている。このような動きと連 動して, 放送事業用マイクロ波帯周波数についても, ディ ジタル化など周波数利用効率の向上に向けた技術的施策の 推進とともに, 固定局 (TSL/STL/TTL) と移動局 (FPU) の周波数分離 (周波数割当ての見直し) や固定局における有 線（光ファイバ）回線の活用などが求められている.また, 併せて, 移動局用 (FPU) 周波数の利用について, 系列局 内における事業者間の相互利用が認められるなどの制度的 な改善も進められている。

\subsection{QAM-FPU}

\subsubsection{QAM-FPUの技術基準}

FPU設備では，OFDMによるSDTV用800MHz帯FPUの ディジタル化が先行し，マラソンや駅伝中継の移動中継3) などの番組制作システムの合理化に大きく貢献した。また， HDTV用には多值FM方式が1998年頃から使用されてきた が，マルチパス，フェーディングおよび隣接チャネル混信 などによる妨害を受けやすく，改善を求められていたとこ ろである。

HDTV用のディジタルFPUとしては，2000年3月に 「QAM-FPU (シングルキャリヤ方式ディジタルFPU) の技 術的条件」の答申が行われ，これを受けて同年10月には， ARIB標準規格 “ARIB STD-B11 2.0版” ${ }^{4)}$ が策定された。

「QAM-FPUの技術的条件」策定に招ける特徴は次の通り である。
（1）HDTV素材伝送に必要なビットレートとして，ARIB 素材伝送開発部会無線素材伝送分科会コーディック 作業班が1999年3月に行った評価実験から, HDTV素 材伝送に必要な映像信号のビットレートを $52 \mathrm{Mbps}$ と して，これに音声信号 (非圧縮4チャネル)，デー夕信 号およびリードソロモン符号 $(\mathrm{R} / \mathrm{S}$ 符号， 188，204) を加え，必要な情報レートを約 $60 \mathrm{Mbps}$ とした。総伝 送レートは，これに3/4畳込み誤り訂正符号 (内符号) と波形等化用基準信号 (19200シンボルにつき256シン

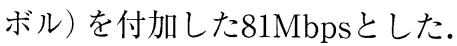

(2) 変調方式としては, 約60Mbpsの情報レートを, 現行 のチャネル間隔 $(18 \mathrm{MHz})$ で隣接チャネルに妨害を与 えず，かつ現行アナログ FMと同等の伝送距離を確保 し, さらに送信出力および帯域幅がなるべく小さい こと,などの条件から「64QAM方式を主体とし, 伝 搬路の状況により，32QAM，16QAMまたはQPSKも 使用できる」こととした。

\subsubsection{QAM-FPU装置の性能と特徵}

QAM-FPUの主要特性についての「技術的条件」と製品比 定格 (例)を表3に，その外観 (例) を図3に示した。

ARIB標準規格 “ARIB STD-B11 2.0版”には，「技術的条 件」に規定されていない，マッピング，波形等化用基準信 号，TMCCのビット配列，インタフェース条件などメーカ 間の互換性確保に必要な規格も規定されている.

現用HDTVコーデックは，まだまだ外形・重量とも大き

\begin{tabular}{|c|c|c|}
\hline 項 目 & 情報通信技術分科会答申「技術的条件」 & 製品化定格(例) \\
\hline 使用チャネル & Bバンド,Cバンド,Dバンド,Eバンド,Fバンド, Gバンド & $\mathrm{D} 8 / \mathrm{D} 12 / \mathrm{E} 8 / \mathrm{F} 4$ \\
\hline 送信電力 & $\begin{array}{l}0.5 \mathrm{~W} \text { 以下 (アナログ回線への妨害がない 場合に限り } 1.5 \mathrm{~W} \\
\text { 以下. } 10.60 \mathrm{GHz} \sim 10.68 \mathrm{GHz} \text { につてては, } 0.5 \mathrm{~W} \text { 以下) }\end{array}$ & $\begin{array}{c}\text { デシタル }: 1.5 \mathrm{~W} / 1.0 \mathrm{~W} / 0.5 \mathrm{~W} / 0.1 \mathrm{~W} \\
\text { アナログ: } 5.0 \mathrm{~W} / 1.0 \mathrm{~W} / 0.5 \mathrm{~W} \\
\text { (ただし, } \mathrm{F} 4 \text { はいずれも } 0.5 \mathrm{~W} \text { ) }\end{array}$ \\
\hline $\begin{array}{l}\text { 変調方式と } \\
\text { 伝送レート }\end{array}$ & $\begin{array}{c}\text { 64QAM (81.0Mbps以下)/ } \\
\text { 32QAM (67.5Mbps以下)/ } \\
\text { 16QAM(54.0Mbps以下)/ } \\
\text { QPSK (27.0Mbps以下) }\end{array}$ & $\begin{array}{c}64 \mathrm{QAM}(\text { 最大 } 79.056 \mathrm{Mbps}) / \\
\text { 32QAM }(\text { 最大 } 65.880 \mathrm{Mbps}) / \\
16 \mathrm{QAM}(\text { 最大 } 52.704 \mathrm{Mbps}) / * 1\end{array}$ \\
\hline 占有周波数帯幅 & $\begin{array}{c}15.5 \mathrm{MHz} \text { 以下 } \\
\end{array}$ & 15.5MHz以下 \\
\hline サイドローブ特性 & $\begin{array}{c}\text { 指定周波数 } \pm 18 \mathrm{MHz} \text { 以上離れた周波数において }-37 \mathrm{~dB} \text { 以下 } \\
\text { (指定周波数基準) }\end{array}$ & 同 左 \\
\hline シンボルレート & 13.5MS/s以下 & $13.35403 \mathrm{MS} / \mathrm{s}$ \\
\hline 送信周波数安定度 & $20 \times 10 \mathrm{E}-6$ 以下 & $10 \times 10 \mathrm{E}-6$ 以下 \\
\hline スプリアス強度 & $100 \mu \mathrm{W}$ 以下 & $50 \mu \mathrm{W}$ 以下 \\
\hline ロールオフ率 & $30 \%$ 送受ルート配分 & 同 左 \\
\hline 入カインタフェース & - & DSB - ASI (204bytes/Packet with 16dummy bytes) \\
\hline コーディック & & SDTVコーディック内蔵 (HDTVコーディックは外付) \\
\hline $\begin{array}{l}\text { 外形寸法 }(\mathrm{m} / \mathrm{m}) \\
\text { (送信機,受信機共通) } \\
\end{array}$ & - & $\begin{array}{c}\mathrm{W} 180 \times \mathrm{H} 100 \times \mathrm{D} 350 \text { (高周波部) } \\
\mathrm{W} 180 \times \mathrm{H} 100 \times \mathrm{D} 350 \text { (制御部 }) \\
\end{array}$ \\
\hline 重量(実測値) & - & $\begin{array}{l}\text { 高周波部: } 7.4 \mathrm{Kg} \text { (送信 }) / 4.8 \mathrm{Kg} \text { (送信 }) \\
\text { 高周波部: } 6.6 \mathrm{Kg} \text { (受信 }) / 4.7 \mathrm{Kg} \text { (受信 }) \\
\end{array}$ \\
\hline
\end{tabular}

*1 波形等化用基準信号を除く.実際に運用する情報レート (TSレート+R/Sレート)は表 1 参照. 


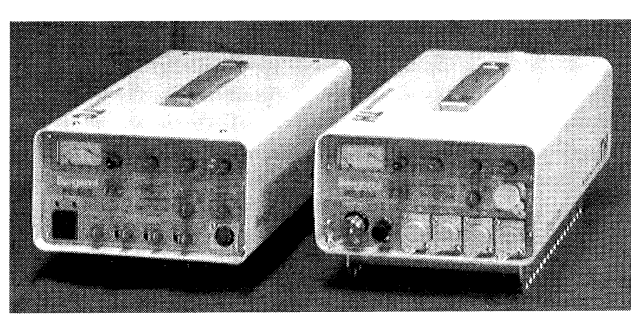

送信制御部 送信高周波部 FPU-TX外観図

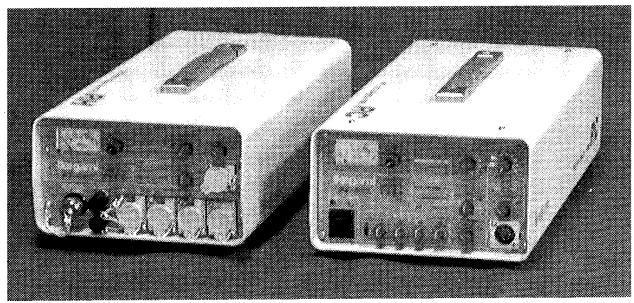

受信高周波部

受信制御部

FPU-RX外観図

図3 QAM-FPUの外観図

い $($ エンコーダが，W430×H88×D600mm. デコーダが, $\mathrm{W} 430 \times \mathrm{H} 44 \times \mathrm{D} 600 \mathrm{~mm}$ 程度) が，いずれ制御部に実装でき る程度への小型・軽量・省電力化を目標に開発が進められ ている。また, FPU本体についても, PA部の高出力化や 直線性の改善, マイクロ波带発振器の位相雑音特性の改善, 機器全般にわたる小型・軽量・省電力化などに向けた回路 設計，構造設計，部品選定に工夫が凝らされているほか, FPU特有の過酷な使用条件を考虑した熱处理対策, 耐震対 策が検討されている.

製品化(例) では, HDTV信号の伝送用として, HD60 （情報レート $=59.648 \mathrm{Mbps}$, 変調方式 $=64 \mathrm{QAM}$, 誤り訂正 $=5 / 6)$, HD50 (52.704Mbps, 32QAM, 4/5), HD45 (44.736Mbps, 32QAM, 4/5), HD40 (39.528Mbps, 16QAM，3/4), HD26 (26.352Mbps, 16QAM, 1/2)の5種 類を準備しているほか, QPSKの運用モードも設定可能と している. 現状では，SNGとの互換を考虑した運用モード を設定して扮り，このような多様な運用モードとしている が, コーデイックの圧縮技術も向上しており，今後は伝送 品質と回線信頼度の両面から最適な運用パラメー夕を確定 し，運用モードの絞り达みを進める予定である。また，製 品化 (例) では, 現行アナログ方式からのスムースな移行を 配慮し，アナログFM伝送も可能な構成としている.

QAM-FPUでは，19,200シンボル長の各ブロックの先頭 に256シンボル長の波形等化用基準信号, 後尾にスタッフ イング信号が挿入されるため, 実際に伝送可能な情報レー 卜は若干低下する。挿入した波形等化用基準信号を利用し た自動波形等化により，マルチパスなどに対する耐性が大
きく改善されている．また，波形等化用基準信号には，変 調方式，誤り訂正，などの送信側伝送モードの表示・制御 情報信号（TMCC. 16シンボルをBPSK変調で使用）が含ま れて抢り，この情報を利用して受信側機器の伝送パラメー 夕を自動設定することができる.

このような, 自動波形等化の機能により, ヘリコプタか らの64QAM-FPUによるハイビジョン空撮映像伝送も実用 化されているとの報告もある。これは，ヘリコプタの機体 の左右に装備した送信アンテナを，データの乗らない参照 信号期間内に切替えて $64 \mathrm{QAM}$ 信号を伝送するというシス テムである．またアナログFMでは，反射がひどく使用で きない市街地に扔いて，QAM-FPUを使用して反射波を拾 った中継ができたという報告もあり，今後の展開が期待さ れている.

\subsection{OFDM-FPU}

\subsubsection{OFDM-FPUの技術基準}

OFDM-FPUについては，2000年10月に「技術的条件」の 答申が行われ，これを受けて2002年3月にARIB標準規格 “ARIB STD-B33 1.0版”5)が制定された。「OFDM-FPUの技 術基準」策定における特徴は次の通りである。

（1）伝送に必要な情報レートは，QAM-FPUと同じ約 60Mbpsとしたが, ガードインターバル, 内符号誤り 訂正, TMCCなどを付加するため, 所要伝送レート は105MbpsとQAM方式に比べ大きな值となってお り, 占有帯域幅も広がっている.

（2）各キャリヤの変調方式としては，64QAM方式を主体 とし, 32QAM, 16QAM, QPSK, DQPSK, BPSK またはDBPSKも使用できることとした。また，移動 伝送のみに使用する装置については16QAMのみとす ることも認められている.

（3）チャネル割当 (周波数間隔)は，現行通りの $18 \mathrm{MHz}$ けでなく, 周波数間隔を $9 \mathrm{MHz}$ としたハーフバンド運 用 (占有带域幅 $8.5 \mathrm{MHz}$ ) が認められた。

\subsubsection{OFDM-FPU装置の性能と特徵}

OFDM-FPUの主要特性についての「技術的条件」と製品 化定格（例）を表4に示した. 外形寸法や重量については, QAM-FPUと同等とすることを目標に製作が進められてい る.

ARIB標準規格「ARIB STD-B33 1.0版」には, FFTポイン 卜数, キャリヤ数, FFTサンプリングクロック周波数, ガ ードインターバルなどの伝送パラメータや伝送容量, イン タフェース条件などメーカ間の互換性確保に必要な規格も 規定されている. OFDM-FPUでは，ハーフバンド運用の

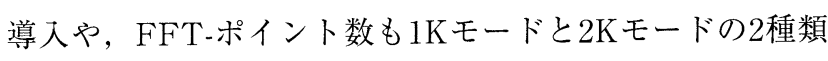
が設定されるなど，多彩な運用モードが搭載される。表4 の製作(例)では，QAM-FPUと同様に，SNGとの互換を考 慮した運用モードを設定しているが，今後は伝送品質と回 線信頼度の両面から最適な運用パラメー夕を確定し, 運用 


\begin{tabular}{|c|c|c|c|c|c|}
\hline \multirow{2}{*}{\multicolumn{2}{|c|}{ 項 目 }} & \multicolumn{2}{|c|}{ 情報通信技術分科会答申の「技術的条件」 } & \multicolumn{2}{|c|}{ 製品化定格(例) } \\
\hline & & フルモード & ハーフモード & フルモード & ハーフモード \\
\hline \multicolumn{2}{|c|}{ 使用周波数 } & $\begin{array}{l}\mathrm{B} \text { バンド,Cバンド,Dバンド, } \\
\mathrm{E} \text { バンド,Fバンド,Gバンド }\end{array}$ & $\begin{array}{l}\text { 800MHz帯, Bバンド,Cバンド, } \\
\mathrm{D} \text { バンド,Eバンド, } \\
\text { Fバンド, Gバンド, }\end{array}$ & "D8/D12/E8/F4 & $\begin{array}{l}\text { D8L/D8U/D12L/D12U/E8L } \\
\text { E8L/E8U/F4L/F4U }\end{array}$ \\
\hline \multirow[t]{2}{*}{ 送信電力 } & 隣接チャネルに & $5.0 \mathrm{~W}$ 以下 $* 1$ & $\begin{array}{c}2.5 \mathrm{~W} \text { 以 } * 1 \\
(800 \mathrm{MHz} \text { 带は } 5 \mathrm{~W} \text { 以下 })\end{array}$ & \multirow{2}{*}{$\begin{array}{c}\text { OFDM: } 0.5 \mathrm{~W} / 0.2 \mathrm{~W} / 0.1 \mathrm{~W} \\
\text { アナログ: } 5.0 \mathrm{~W} / 0.5 \mathrm{~W} / 0.1 \mathrm{~W} \\
(\mathrm{~F} 4 \text { は } 0.5 \mathrm{~W})\end{array}$} & \multirow[t]{2}{*}{$0.5 \mathrm{~W} / 0.2 \mathrm{~W} / 0.1 \mathrm{~W}$} \\
\hline & $\begin{array}{l}\text { 隣接チャネルに } \\
\text { アナログ有り }\end{array}$ & $0.2 \mathrm{~W}$ 以下 & $\begin{array}{c}0.1 \mathrm{~W} \text { 以下 } \\
(800 \mathrm{MHz} \text { 帯は5W以下 })\end{array}$ & & \\
\hline \multicolumn{2}{|c|}{$\begin{array}{l}\text { キャリヤの変調方式と } \\
\text { 伝送レート/最大情報レート*2 }\end{array}$} & $\begin{array}{c}\text { 64QAM(105.0Mps以 } * 3 \\
\text { 32QAM (87.5Mp以下) } \\
\text { 16QAM (70.0Mps以下) } \\
\text { QPSK/DQPSK (35.0Mps以下) } \\
\text { BPSK/DBPSK (17.5Mps以下) }\end{array}$ & $\begin{array}{c}\text { 64QAM (51.0Mps以下)*3 } \\
\text { 32QAM (42.5Mps以下) } \\
\text { 16QAM (34.0Mps以下) } \\
\text { QPSK/DQPSK (17.0Mps以下) } \\
\text { BPSK/DBPSK (8.5Mps以下) }\end{array}$ & $\begin{array}{l}\text { 64QAM 5/6 (最大 } 59.648 \mathrm{Mbs}) \\
64 \mathrm{QAM} 3 / 4 \text { (最大 } 53.683 \mathrm{Mbps}) \\
32 \mathrm{QAM} 3 / 4 \text { (最大 } 44.736 \mathrm{Mbs}) \\
\text { 32QAM } 2 / 3 \text { (最大 } 39.765 \mathrm{Mbs}) \\
16 \mathrm{QAM} 2 / 3 \text { (最大 } 31.812 \mathrm{Mbps} \text { ) } \\
\text { DQPSK } 1 / 2 \text { (最大 } 14.912 \mathrm{Mbps} \text { ) } \\
\text { DBPSK } 1 / 2 \text { (最大 } 7.456 \mathrm{Mbps} \text { ) }\end{array}$ & $\begin{array}{c}\text { 32QAM 5/6 } \\
\text { (最大 } 24.853 \mathrm{Mbps} \text { ) } \\
16 \mathrm{QAM} 2 / 3 \\
\text { (最大 } 15.906 \mathrm{Mbps} \text { ) }\end{array}$ \\
\hline \multicolumn{2}{|c|}{ FFTポイント数 } & - & - & \multicolumn{2}{|c|}{$1024 / 2048$} \\
\hline \multicolumn{2}{|c|}{ FFTサンプリングクロック $(\mathrm{MHz})$} & - & - & \multicolumn{2}{|c|}{20.45074} \\
\hline \multicolumn{2}{|c|}{ キャリヤ数(総数/データ) } & - & - & $857(672) / 1721(1344)$ & $425(336) / 841(672)$ \\
\hline \multicolumn{2}{|c|}{ ガードインターバル比 } & - & - & \multicolumn{2}{|c|}{$1 / 8$} \\
\hline \multicolumn{2}{|c|}{ 占有周波数帯幅 } & $17.5 \mathrm{MHz}$ 以下 & $8.5 \mathrm{MHz}$ 以下 & \multicolumn{2}{|l|}{$17.12 \mathrm{MHz} / 17.19 \mathrm{MHz}$} \\
\hline \multicolumn{2}{|c|}{ サイドローブ特性 } & $\begin{array}{l}\text { 指定周波数 } \pm 9 \mathrm{MHz} \text { 以上離れた } \\
\text { 周波数において }-37 \mathrm{~dB} \text { 以下 } \\
\text { (指定周波数基準) }\end{array}$ & $\begin{array}{l}\text { 指定周波数士 } 4.5 \mathrm{MHz} \text { 以上離れた } \\
\text { 周波数において }-37 \mathrm{~dB} \text { 以下 } \\
\text { (指定周波数基準) } \\
\end{array}$ & \begin{tabular}{|l|} 
指定周波数 $\pm 9 \mathrm{MHz}$ 以上離れ \\
た周波数において $-37 \mathrm{~dB}$ 以下 \\
(指定周波数基準)
\end{tabular} & \begin{tabular}{|l} 
指定周波数 $\pm 4.5 \mathrm{MHz}$ 以上 \\
離れた周波数に扔いて -37 \\
dB以下(指定周波数基準)
\end{tabular} \\
\hline \multicolumn{2}{|c|}{ 送信周波数安定度 } & $7.0 \times 10^{-6}$ 以下 & $\begin{array}{c}7.0 \times 10^{-6} \text { 以下 } \\
\left(800 \mathrm{MHz} \text { 帯は } 1.5 \times 10^{-6} \text { 以下 }\right) \\
\end{array}$ & $7.0 \times 10^{-6}$ 以下 & $7.0 \times 10^{-6}$ 以下 \\
\hline \multicolumn{2}{|c|}{ スプリアス強度 } & $50 \mu \mathrm{W}$ 以下 & $\begin{array}{c}50 \mu \mathrm{W} \text { 以下 } \\
(800 \mathrm{MHz} \text { 带は } 25 \mu \mathrm{W} \text { 以下 })\end{array}$ & $50 \mu \mathrm{W}$ 以下 & $50 \mu \mathrm{W}$ 以下 \\
\hline \multicolumn{2}{|c|}{ デイジタル用入出力インタフェース } & - & - & \multicolumn{2}{|c|}{ DSB - ASI (204bytes/Packet with 16dummy bytes)) } \\
\hline \multicolumn{2}{|c|}{ コーデック } & - & - & \multicolumn{2}{|c|}{ SDTVコーデック内蔵(HDTVコーデックは外付) } \\
\hline \multicolumn{2}{|l|}{ その他 } & - & - & \multicolumn{2}{|c|}{ アナログFM(SDTV)用変調器内蔵 } \\
\hline
\end{tabular}

*1 $\quad 10.60 \mathrm{GHz} \sim 10.68 \mathrm{GHz}$ につては0.5W以下

*2「技術的条件」では伝送レートを, 製品化定格では最大情報レート（TSレート+RSレート）記載。実運用に使用する情報レートは表 1 を参照

*3「移動伝送のみに使用する場合(16QAMのみとすることができる)」を除き,64QAM必須

表 4 OFDM-FPUの技術的条件と製品化定格（例）

モードの絞り込みを進める方針とアナログ方式からのスム 一スな移行を配慮する考えから，アナログFM伝送も可能 な構成とした点はQAM-FPUの場合と同様である.

OFDM方式の特徽として，マルチパス耐性に強いことが 挙げられている。 そこで, OFDM-FPUでは, SDTV対応で はあるが，多値度の低いQPSK変調（誤り訂正 $=1 / 2 ，$ 情報 レート $=14.91 \mathrm{Mbps}$ ) やBPSK変調方式 (誤り訂正 $=1 / 2$, 情

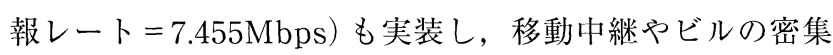
した市街地などでの運用にも配慮している。また，FPUと しては, 初めてハーフバンド運用が認められ，SDTV伝送 では, アナログ方式の 2 倍の回線設定が可能になるなど, 周波数の一層の効率的運用が可能になった.

OFDM-FPUについては，まだメーカ各社の製品化作業 中で，2002年7月にARIBに抏いてメーカ間の互換性確認な どのテストが行われ, 特性改善の作業が進められている.

OFDM-FPUについては，QAM方式以上に厳しいPAの直 線性確保や，マルチパス対策，自動スタッフィング技術の
開発など,メーカ各社がしのぎを削っている状況にある. OFDM-FPUは，マルチパス耐性に強く移動伝送に有利と いわれているが，QAM-FPUとの実証比較などを行った上 で今後の整備方針を早急に確定していくことが必要である が，メーカ間互換の確保など, 今後に残された課題も少な くない.

\section{4. ディジタルTSLとSTL/TTL}

\section{1 ディジタルTSLとSTL/TTLの技術的条件}

「ディジタルTSLの技術的条件」は2000年3月QAM-FPUと 同時に,「ディジタルSTL/TTLの技術的基準」は2002年1月 に情報通信技術審議会答申が行われ，制度整備が進められ てきた。

ディジタルTSLおよびディジタルSTL/TTLの主要特性 の「技術的条件」を表5に示した. ディジタルSTL/TTLに は, 地上デジタル放送の信号をそのままマイクロ波帯の周 波数に変換して伝送するIF方式と, 地上デジタル放送のト 


\begin{tabular}{|c|c|c|c|}
\hline & \multirow[t]{2}{*}{ ディジタルTSL (QAM方式) } & \multicolumn{2}{|c|}{ ディジタルSTL\&TTL } \\
\hline & & IF伝送方式 & T S 伝送方式 \\
\hline 対象周波数 & 放送業務用Aバンド〜Gバンド & 放送業務用Aバンド〜Gバンド & $\begin{array}{l}\text { 放送業務用Aバンド〜Gバンドおよび } \\
\text { 公共·一般業務用 } 6.5 / 7.5 \mathrm{GHz} \text { 带 } \\
\end{array}$ \\
\hline 変調方式 & 64QAM & $\begin{array}{c}\text { "ISDB-T"(地上デジタル放送波と同一) + } \\
\text { (SC/QPSK) }\end{array}$ & 64QAM \\
\hline 伝送容量 & 84.0Mbps以下 & $\begin{array}{l}\text { 1)"ISDB-T"信号+(SC+パイロット信号) } \\
\text { 2) SCは, 160kbps以下 }\end{array}$ & 40.2Mbps以下 \\
\hline クロック周波数 & 14.0MHz以下 & - & 6.7MHz以下 \\
\hline 最大空中線電力 & 2W以下 (4W以下)*1 & $2 \mathrm{~W}$ 以下 (4W以下) *1 & 2W以下 (4W以下)*1 \\
\hline 周波数間隔 & $18 \mathrm{MHz}$ & $\begin{array}{l}\text { 1) } 6 \mathrm{MHz} \text { (独立同期, SCなし) } \\
\text { 2) } 9 \mathrm{MHz} \text { (従属同期) }\end{array}$ & $9 \mathrm{MHz}$ \\
\hline 最大占有带域幅 & 16.2MHz以下 & $\begin{array}{l}\text { 1) } 5.7 \mathrm{MHz} \text { 以下(独立同期,SCなし) } \\
\text { 2） } 8.4 \mathrm{MHz} \text { 以下(従属同期) }\end{array}$ & 7.6MHz以下 \\
\hline $\begin{array}{l}\text { 標準受信入力 } \\
\text { (最大受信入力) }\end{array}$ & $\begin{array}{r}\mathrm{A} \text { バンド: }-56.9 \mathrm{dBm}+\mathrm{Fmr} / 2(-36 \mathrm{dBm}) \\
\mathrm{B} \sim \mathrm{D} \text { バンド: }-58.5 \mathrm{dBm}+\mathrm{Fmr} / 2(-36 \mathrm{dBm}) \\
\mathrm{E} \sim \mathrm{F} \text { バンド: }-49.1 \mathrm{dBm}+\mathrm{Zr} / 2(-27 \mathrm{dBm}) \\
\mathrm{G} \text { バンド: }-50.8 \mathrm{dBm}+\mathrm{Zr} / 2(-27 \mathrm{dBm}) \\
\mathrm{G} \text { バンド: }-50.8 \mathrm{dBm}+\mathrm{Zr} / 2(-27 \mathrm{dBm}) \\
\end{array}$ & $\begin{array}{r}\mathrm{A} \text { バンド: }-56.9 \mathrm{dBm}+\mathrm{Fmr} / 2(- \\
\mathrm{B} \sim \mathrm{D} \text { バンド: }-58.5 \mathrm{dBm}+\mathrm{Fmr} / 2(- \\
6.5 / 7.5 \mathrm{GHz} \text { バンド }:-54.5 \mathrm{dBm}+\mathrm{Fmr} / 2(- \\
\mathrm{E} \sim \mathrm{F} \text { バンド }:-49.1 \mathrm{dBm}+\mathrm{Zr} / 2(-2\end{array}$ & $\begin{array}{l}-36 \mathrm{dBm}) \\
-36 \mathrm{dBm}) \\
-36 \mathrm{dBm} . \text { 単一受信はー44dBm) } \\
27 \mathrm{dBm})\end{array}$ \\
\hline 周波数偏差 & $20 \times 10 \mathrm{E}-6$ 以下 & $\begin{array}{l}\text { 送信周波数偏差が, } 20 \times 10 \mathrm{E}-6 \text { 以下で,かつ受信 } \\
\text { IF周波数の偏差が, MFNの場合を除き } \pm 1 \mathrm{~Hz} \text { 以下 }\end{array}$ & $20 \times 10 E-6$ 以下 \\
\hline 送信出力フィル夕 & 規定なし & 省 & 略 \\
\hline 送受信空中線特性 & 省 略 & 省 & 略 \\
\hline 送信電力スペクトラム & $-37 \mathrm{~dB} / \mathrm{f0} \pm \mathrm{fc}(14 \mathrm{MHz})$ & $\begin{array}{c}-32 \mathrm{~dB} / \mathrm{f} 0 \pm 3.3 \mathrm{MHz} \sim 4.5 \mathrm{MHz} \\
-47 \mathrm{~dB} / \mathrm{fO} \pm 4.5 \mathrm{MHz} * 2\end{array}$ & $-37 \mathrm{~dB} / \mathrm{f0} \pm 4.5 \mathrm{MHz}$ \\
\hline スプリアス強度 & $100 \mu \mathrm{W}$ 以下 & $100 \mu \mathrm{W}$ 以下で,かつ基本周波数の平均電力より 43 & $+10 \log 10 \mathrm{P}(\mathrm{dB})$ 低い值 $[\mathrm{P}(\mathrm{W})$ : 平均電力] \\
\hline $\begin{array}{ll}* 1 & \text { 反射板を使用す } \\
& \text { ただし, 10.60〜10 } \\
* 2 & \text { サービスチャネル }\end{array}$ & $\begin{array}{l}\text { 線, 長い給電線を使用する場合など, 特殊 } \\
\text { GHzについて } \\
\text { 使用しない独立同期の場合.従属同期方式 }\end{array}$ & $\begin{array}{l}\text { 条件下では, ( )内の出力とすることができる. } \\
\text { ついては参考文献6)参昭 }\end{array}$ & \\
\hline
\end{tabular}

\section{表 5 ディジタルTSLとディジタルSTL/TTLの主要規格}

ランスポートストリームの信号にTMCC信号やサービス・ チャネルを時分割多重して伝送するTS方式がある。

「ディジタルTSLの技術的基準」策定における特徴は次の 通りである。

（1）TSL回線の最大伝送容量は, FPUの最大伝送容量に 受信基地局の制御信号を加えた $84 \mathrm{Mbps}$ とた. TSL 回線はHDTV素材1回線としてだけではなく, 時分割 多重により複数素材 (例えば, SDTV $(20 \mathrm{Mbps}) \times 3$ 回 線など)の伝送回線として利用することも可能である.

(2) チャネルセパレーションは従来通り $18 \mathrm{MHz}$ とし, 占 有帯域幅は, $\mathrm{A}$ バンド〜 Gバンドの全バンドで $16.2 \mathrm{MHz}$ とした。

（3）空中線電力は, 現在のアナログFM回線 (最大 $15 \mathrm{~W}$ ) を代替できることが必要なことから，状況によって は最大 $4 \mathrm{~W}$ (原則 $2 \mathrm{~W})$ まで許容される.

一方,「ディジタルSTL/TTLの技術的基準」についての特 徴は次の通りである。

（1）HDTV番組伝送時においても，占有周波数帯幅が従 来のアナログFM方式の半分となり，隣接周波数の使 用も可能である（TS方式においては，地上デジタル 放送に必要な情報容量 $(32.5 \mathrm{Mbps})$ に付加信号, サー
ビスチャネル信号および誤り訂正信号を付加し，総 伝送レートは約40.2Mbpsであり，64QAM変調方式と した場合の占有带域幅は約 $7.6 \mathrm{MHz}$ となる。IF方式で は, サービスチャネル用信号 (補助信号) および周波 数安定化のために使用するパイロット信号を周波数 多重しても，8.4MHz以下である).

（2）公共・一般業務用の周波数帯である6.5GHz/7.5GHz带 の共用が可能になった.

(3) TS伝送方式を原則に, 中継回線の構築上必要と認め られる場合は，他の回線への周波数割当てに影響を 与えない範囲で，SFNの同期が容易なIF伝送方式も 使用できる $(6.5 / 7.5$ 帯を除く)こととし，状況に応じ た柔軟なシステム構築を可能とした.

(4) 回線設計 (回線品質)において必要とされる空中線電 力は $1.5 \mathrm{~W}$ 程度であることから, 空中線電力の最大值 は原則 $2 W$ とたが, 給電線が長い場合や無給電中継 装置 (反射板) を使用する場合など，特に必要と認め られる場合には，4Wを上限とする空中線電力を設定 することができる。

4.2 ディジタルTSLとSTL/TTL装置の性能と特徵 情報通信技術審議会の「技術的条件」の答申後, ARIBで 


\begin{tabular}{|c|c|c|}
\hline & IF 方式(スタジオ変調方式) & T S 方式(送信所変調方式) \\
\hline チャネルセパレーション & 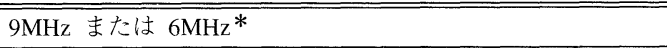 & $9 \mathrm{MHz}$ \\
\hline 経済性 & $\begin{array}{l}\text { スタジオに置く1台のOFDM変調器で良いので, } \\
\text { システム構成は比較的シンプル }\end{array}$ & 送信所ごとにOFDM変調器が必要なので,構成はやや複雑 \\
\hline SFNの構築 & SFNのシステム構築の考え方が容易 & 送信所ごとに置かれたOFDM変調器の同期をとる必要がある \\
\hline リモコン制御信号等の伝送 & 副搬送波をQPSK変調(周波数分割多重) & 時分割多重 \\
\hline 回線信頼度 & $\begin{array}{l}\text { (1)機器のC/N劣化などがそのまま放送回線のC/Nに影響する } \\
\text { (2)フェージングにより,放送エリアが変動する } \\
\text { (3) 千涉などによる影響を受け易い }\end{array}$ & $\begin{array}{l}\text { (1) 機器のC/N劣化が放送回線のC/Nに影響することはない } \\
\text { (2)フェージングにより,放送エリアが変動することはない } \\
\text { (3) 干渉なとにによる影響を受けにくい }\end{array}$ \\
\hline
\end{tabular}

* 独立同期方式で,リモコン制御信号等(サービスチャネル)も付加しないときは $6 \mathrm{MHz}$

\section{表 6 ＴSS方式とIF方式の特徵}

は，「テレビジョン放送番組素材伝送用固定形マイクロ波 帯ディジタル無線伝送システム（TSL）標準規格“ARIB STD-B12 2.0版” ل吕 および「テレビジョン放送番組素材伝送 用固定形マイクロ波带ディジタル無線伝送システム （STL/TTL）標準規格“ARIB STD-B35 1.0版”」7)を策定し た。前者には，「技術的条件」に規定されていないインタフ エース条件やメーカ間の互換性確保に必要な規格が規定さ れているが，後者には，残念ながらインタフェース条件や メーカ間の互換性確保に必要な規格は規定されていない. 周辺設備 (マス夕送出機器や中継局用OFDM変調器など) やSFN同期システム（従属同期方式と第3者同期方式の 2 案 が提案されている) とのインタフェース規格や，誤り訂正 についての規格，および，メ一力互換確保のための規格な どの策定を期待したい.

なお，ディジタルTSL設備については，製品化実績が1 例だけ報告8)されているが，ディジタルSTL/TTLについ ては，まだ製品化例はない。ディジタルSTL/TTLについ て，TS方式とIF方式の特徴を表6に示した。両方式につい ての実機比較などはまだ実施されていない状況にあり，今 後に残された課題も多い.

\section{5.むすび}

2003年末の地上デジタル放送の開始に向け，スポーツイ ベントを中心に，HDTV素材の伝送設備の整備が急がれて いる。ここでは，その中核となるSNG，QAM-FPU， OFDM-FPUおよびTSLと，地上デジタル放送の中継ネッ トワークの構成に欠かせないSTL/TTLの最新状況を報告
した。

最後に，情報提供をいただいたNHK，ARIB，NEC，日 立国際電気，三菱電機ならびに池上通信機の関係各位に深 く感謝致します。

(2002年6月27日受付

\section{〔文 献〕}

1）（社）電波産業界：“HDTVデイジタルSNG伝送システム標準規格； ARIB STD-B26 1.0版”(平成12年7月26日)（July 2000)

2）総務省 総合通信基盤局電波部電波政策課：“固定通信システムによる マイクロ波带の利用に関する調査検討会報告書”（2001年6月29日） (June 2001)

3）廣野ほか：“800MHzOFDM-FPUによる東京マラソン生中継システム”, 民放技術報告会，10（1999）

4）（社）電波产業界：“テレビジョン放送番組素材伝送用可搬型QAM方 式ディジタル無線伝送システム 標準規格；ARIB STD-B112.0版” (平 成12年10月12日）(Oct. 2000)

5）（社）電波産業界：“テレビジョン放送番組素材伝送用可搬型OFDM 方式ディジタル無線伝送システム 標準規格; ARIB STD-B33 1.0版” （平成14年3月28日）（Mar. 2002）

6）社）電波産業界：“テレビジョン放送番組素材伝送用固定形マイク 口波带ディジタル無線伝送システム（TSL）標準規格；ARIB STDB12 2.0版”（平成12年10月12日）（Oct. 2000）

7）(社）電波産業界：“テレビジョン放送番組素材伝送用固定形マイク ロ波带ディジタル無線伝送システム（STL/TTL）標準規格；ARIB STD-B35 1.0版”(平成14年7月25日) (July 2002)

8）大野ほか：“番組素材伝送用ディジタルTSL回線設備の導入”，放送技 術, 11, pp.148-151（2001）

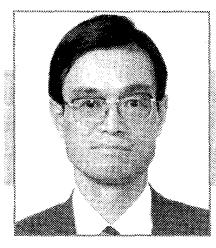

斑籐 新夫 1968年. 東京都立大学工学部電気 工学科卒業。1962年，(株) 東京放送入社。送信技 術部，技術部，ステーション技術センター回線担当 を経て，現在，技術管理センター技術推進にて， SNG送受信設備，FPU/TSL/STL送受信設備およびテ レビ，ラジオ送信設備を担当. 正会員. 